\title{
Carbon Dioxide Emissions From Energy Use And Mitigation Potential Of Household Behavioural Modifications In Kaduna Metropolis, Nigeria
}

\author{
Buhari Mohammed Manzuma ${ }^{1 *}$, Ikemefuna Mbamali ${ }^{1}$, Andrew Mhya Stanley ${ }^{1}$ and \\ Maaruf Sani \\ ${ }^{1}$ Department of Building, Faculty of Environmental Design, Ahmadu Bello University, Zaria, \\ Nigeria \\ ${ }^{2}$ Department of Urban \& Regional Planning, Faculty of Environmental Design, Ahmadu Bello \\ University, \\ *bmmanzuma@abu.edu.ng
}

Received : 31 January 2017 Final Version Received: 23 January 2018

\begin{abstract}
Some activities in all types of buildings contribute to greenhouse gas, GHG, emissions. This is especially so in case of residential buildings in cities as it has been observed that urban residents spend the greater part of their time indoors. During this time man is engaged in emission producing activities such as respiration, energy generation and consumption and waste generation. The behaviour of the users of buildings greatly influences the quantities of the GHGs resulting from their activities. There are certain ways of doing things especially in connection with energy use in buildings that have been identified to be more efficient and consequently less emission intensive than others. This study investigated the extent of observance of these energy efficient practices by the surveyed households and their willingness to adopt measures that will significantly reduce their carbon footprint. The findings show a generally low level of observance of the measures by the households but they also show a high level of readiness to adopt the suggested measures. The study concludes that emission of large quantities of carbon dioxide by the surveyed houses can be avoided and recommends a creation of awareness among households about these practices by the relevant stakeholders.
\end{abstract}

Keywords: Behavioural, Greenhouse Gas, Household, Mitigation, Modifications and Residential.

\section{INTRODUCTION}

Energy in various forms is used for different processes in residential buildings. Various activities that consume energy in buildings are lighting, ventilation and cooling, cooking and powering of other domestic appliances. Energy consumption for these processes can amount to a significant share of global annual energy consumption. The United Nations Environment Programme, UNEP, (2007) observed that the utilization of energy and the associated greenhouse gas (GHG) emission in the building sector adds up to between 30 and $40 \%$. The UNEP sustainable building and climate initiative, UNEP SBCI, (2009) asserts that the building sector uses up $40 \%$ of all generated energy and give off not less than $30 \%$ of worldwide GHG emissions annually.

It has been observed that if the momentum of growth in the development of new infrastructural facilities in transiting economies of the world are maintained and coupled with the inefficiencies of existing building stock worldwide, then urgent and far-reaching measures may need to be taken to avoid doubling the emission of greenhouse gases as a result of activities associated with the use of buildings in just over a decade from now. In most countries the residential sector accounts for the major share of total primary energy consumption. Takaoka (2011) pointed out that it is possible to reduce 
energy consumption in the newly constructed as well as old buildings by as much as between 30 to $50 \%$ by the year 2020 . It is this identified potential of the sector globally that this study intends to investigate the extent to which it applies to the case study.

Climate scientists are of the view that if dangerous interference with the global climate system is to be avoided, then atmospheric emission concentration must be reduced to close to pre-industrial era level of around 300 parts per million, (ppm). Making this a reality calls for action from all the stakeholders including environmentalists, built environment professionals, relevant government agencies, real estate developers and administrators, building owners and users, etc. The role that can be played by the building sector generally and in particular the residential sub-sector is very crucial because of the contributions of the sector in terms of energy consumption and the consequent emission of greenhouse gases (UNEP, 2009). For this emission reduction potential from the building sector to be properly harnessed, there is the need to first understand how much is being emitted, from which activities, identification of areas of wastages and how these can be eliminated. This is usually actualized with the formation of baselines for energy consumption by the surveyed buildings and emissions resulting from that (Global Commission on the Economy and Climate, 2015; Gupta and Garrigan, 2013).

GHG emissions are directly related to energy consumption and attempts at cutting down on the level of emissions will also promote energy efficiency. This assertion is corroborated by Department of Energy \& Climate Change (2015) in the proclamation that climate change, greenhouse gas emission and energy use are inextricably linked. The concept of energy efficiency is of great importance especially in countries like Nigeria where the supply of electricity to the various sectors is insufficient.

Mills (2011), UNEP (2009) and Erickson, Heaps and Lazarus (2009) variously opined that attempts at reducing emissions from buildings is a worthwhile exercise because of the numerous benefits that come with it to both the economy and to society. They observed that if greenhouse gas mitigation strategies for buildings are thoughtfully planned and implemented, they are not only capable of stimulating the growth of new businesses and jobs but also other benefits such as better housing and access to clean energy and water. In addition to the aforementioned benefits, Swinand and O'Mahoney (2014) avowed that energy efficiency in the housing sector will lead to energy security and affordability as well as economic competitiveness and environmental sustainability.

Furthermore the Ministry of Environment of the Federal Republic of Nigeria (2003) view any attempt at identifying ways of reducing future GHG emissions as an important contribution to the sustainable development of the country. The focus of this study is to identify the specific measures through which emissions of greenhouse gases can be significantly reduced from residential buildings in Kaduna.

\section{LITERATURE REVIEW}

\subsection{BUILDINGS AND GHG EMISSIONS}

The majority of greenhouse gas emissions from buildings are in one way or the other related to energy use in the buildings. The GHG emissions from buildings are broadly grouped into two classes namely direct emissions and indirect emissions. The direct emissions are those resulting from the consumption of the different types of fuels mostly fossil fuel and biomass to meet the energy needs of the users of the buildings. For example when a household operates a kerosene stove or a gas cooker for food preparation, carbon dioxide is produced from the process. Likewise when petrol or diesel is used to operate a portable generator by a household to produce electricity when the grid supply is off, direct greenhouse emissions are produced. On the other hand, when households consume grid supplied electricity which has been generated from thermal plants burning gas or coal, they produce indirect emissions. Substantial quantities of greenhouse gas are also released into the atmosphere during the manufacture of some building materials such as insulation materials, and refrigeration and cooling systems (UNEP, 2009).

UNEP (2009) has identified the correlation between the level of GHG emissions from buildings, the quantity of energy consumed and the sources from which it is generated. Lin, Yu, Bai, Feng and Wang (2013) pointed out that aside the energy efficiency of appliances, the lifestyles of the members of a household is another very vital determinant of energy use and the associated GHG emissions.

\subsection{EMISSIONS FROM ELECTRICITY CONSUMPTION}


Electricity from the national grid in Nigeria is generated mostly from thermal plants burning either coal or natural gas with a lesser fraction being generated from hydro plants. Table 1 shows the summary of the installed and available capacities of the generating stations in Nigeria as at 2011. A few power generating stations still burn small quantities of diesel and fuel oil and petrol is used mostly for powering portable generators by households and small businesses while large corporations and government agencies use diesel to operate their generators to augment the shortfall from the national grid (The Ministry of Environment of the Federal Republic of Nigeria, 2003).

Table 1: Summary of Electricity Generation in Nigeria

\begin{tabular}{lllll}
\hline S/no & Classification & Type & \multicolumn{2}{c}{ Capacity (MW) } \\
\cline { 3 - 5 } & & & Installed & Available \\
\hline 1 & $\begin{array}{l}\text { Government } \\
\text { owned power } \\
\text { stations }\end{array}$ & Hydro & 1900 & 1380 \\
2 & $\begin{array}{l}\text { Government } \\
\text { owned power } \\
\text { stations }\end{array}$ & Thermal & 5004.6 & 1978 \\
3 & $\begin{array}{l}\text { Independent } \\
\text { power } \\
\text { projects } \\
\text { National } \\
\text { integrated } \\
\text { power } \\
\text { projects }\end{array}$ & Thermal & 1759 & 1484 \\
& & & \\
\hline Sourcermal & 4775 & 0 \\
\hline Bureau & & & \\
\hline
\end{tabular}

Source: Bureau of Public Enterprises (BPE), 2011.

Table 1 shows the combined available power generation from the three hydro plants at Kainji, Jebba and Shiroro to be $1380 \mathrm{MW}$ while the total available power from the thermal plants is $3462 \mathrm{MW}$. These combine to give a total of 4842MW. The figure given by Awosope (2014) is not too far from this. BPE (2011) gave the average power generation in Nigeria to be $3200 \mathrm{MW}$. Computations from the figures in Table 1 gave $28.5 \%$ of electricity available from the National Grid in Nigeria to be from hydroelectric dams while the remaining $71.5 \%$ is from thermal plants.

The technological advancement of nations brings with it the high probability of growth in the level of greenhouse gas emissions. Two main reasons are given by UNEP (2009) for this. Firstly, the replacement of traditional sources of energy such as fuel wood, charcoal, sawdust and dung in some instances with the more convenient and neater electricity and gas can bring about the need for electrical appliances that could not be used before the advent of electricity. Secondly and even of greater influence is that the generation of electricity on its own is a major emitter of greenhouse gases especially if it is from non-renewable sources such as natural gas and coal as is mostly the case in Nigeria.

\subsection{EMISSIONS FROM ON-SITE ENERGY}

Activities like cooking and lighting are done in many households in Nigeria through the use of fossil-based fuels such as gas (liquefied natural gas and liquefied petroleum gas), kerosene, coal, and biomass such as wood and dung. This is because many of the households are either not connected to grid electricity or the lack of the electricity for use even in the grid-connected houses for the most part of the times. To augment this shortage, many households rely on portable generators for their power needs (Olaleye and Akinbode, 2011; Stanley, Mbamali and Dania, 2012; Mbamali, Stanley and Zubairu, 2012; Mohammed, 2015; Ibrahim, 2015). The generators either use petrol or diesel to operate them both of which emit a lot of GHG gases during their combustion.

The International Energy Agency (2013) has identified energy use as the greatest source of emission out of all the anthropogenic activities that produce greenhouse gases. Wang, Huang and Zou (2016) also observed that more stringent measures need to be taken if significant emission reductions from energy use in buildings are to be achieved. This view point arise from the close relationship between energy consumption and GHG emissions.

\subsection{BEHAVIOURAL MODIFICATIONS}

The energy use in buildings where the control of artificial lighting, ventilation and cooling equipment and fittings are not automated is to a great extent determined by the behaviour of the users of the building. Studies have shown significant variations of energy use in similar buildings with different occupants (Levine, Urge-Vorsatz, Blok, Geng, Harvey, Lang,... and Yoshino, 2007). For example households can change from energy and carbon intensive cooking methods by adopting one or more of these measures: using energy efficient biomass stoves, use of clean cooking fuels such as gas, use of solar cookers, etc.

PEW CENTER (2009) observed that behavioural modifications can be used to reduce energy consumption for artificial lighting. The needed changes in behaviour include keeping on only lights that are needed, adoption of task 
lighting as against general overhead lighting and embracing of technological options such as motion and occupancy sensors as well as timers which control lights automatically and ensure that lights are on only when there is the need for them.

\section{METHODOLOGY}

The study involved a survey of conveniently selected households in Kaduna metropolis. The respondents from the households were asked some questions related to energy use at home and their willingness to shift from present practices to some other more efficient ones capable of cutting down the quantity of $\mathrm{CO}_{2}$ emitted into the atmosphere.

\subsection{THE STUDY AREA}

Kaduna is one of the major commercial cities in Nigeria, second only to Kano in the North. The Kaduna state ministry of land, survey and country planning (2015) listed the city among the five largest in the country. The others are Lagos, Kano, Ibadan and Abuja. Its industrial establishments include textiles, furniture, automobiles (Peugeot Automobile Nigeria), related fabrication industries, Nigerian Breweries and the Nigerian National Petroleum Corporation (NNPC) refinery. Kaduna has an International Trade Fair Complex and it hosts annual trade fairs (Kaduna state, 2010). The city was the second most industrialized in Nigeria after Lagos in the 1970's. However incessant sectarian and ethnic strife has brought about a decline in the economic prosperity of Kaduna in the last twenty to thirty years (Ndabula, Jidauna, Averik, Oyatayo, Abaje and Ali, 2014). A justification of the choice of Kaduna for this study can be found in the assertion that cities accommodate more than half of the global population and produces about $80 \%$ of GHGs globally and yet they do not occupy up to $1 \%$ of the earth surface (Sun, Yuan, Zhang, Wang and Wang, 2014; UNEP, 2015; UNEP, n.d; and UNEP, 2012). Kaduna is a typical city in the Nigerian context.

\subsection{SAMPLE SIZE DETERMINATION}

According to the 2006 National Population and Housing Census in Nigeria, the Kaduna metropolis has a total of three hundred and six thousand, five hundred and eight (306508) regular households (National Population Commission, NPC, 2009a; NPC, 2009b). This figure (306508) forms the population for this study. Israel (2013) suggests that sample size for populations in excess of one hundred thousand $(100,000)$ at $\pm 7 \%$ precision levels and $95 \%$ confidence level is two hundred and four (204). The study was able to retrieve two hundred and eighteen (218) of the two hundred and thirty six (236) questionnaires administered. The defective questionnaires such as those with too many unanswered questions and inconsistent responses were eliminated so as to be left with two hundred and four (204) required for the study.

\section{ENERGY USE PATTERNS AND BEHAVIOURAL ADAPTATIONS}

\subsection{ENERGY USE PREFERENCE}

Households were requested to indicate their level of preference of the identified cooking methods on a scale of $1-5$ where 1 is the most preferred option and 5 is the least preferred. Table 2 presents the responses.

Table 2: Households Preference of Energy Type for Cooking

\begin{tabular}{|c|c|c|c|c|c|c|c|c|}
\hline \multirow{2}{*}{$\begin{array}{l}\text { Energy } \\
\text { Option }\end{array}$} & \multicolumn{5}{|c|}{ Preference / Frequency $(f)$} & \multirow[t]{2}{*}{$\sum f$} & \multirow[t]{2}{*}{ Mean } & \multirow[t]{2}{*}{ Rank } \\
\hline & 1 & 2 & 3 & 4 & 5 & & & \\
\hline $\begin{array}{l}\text { Electric } \\
\text { cooker }\end{array}$ & 68 & 33 & 25 & 8 & 20 & 154 & 2.21 & 2 \\
\hline $\begin{array}{l}\text { Gas } \\
\text { cooker }\end{array}$ & 73 & 39 & 15 & 13 & 20 & 160 & 2.18 & 1 \\
\hline $\begin{array}{l}\text { Kerosene } \\
\text { stove }\end{array}$ & 42 & 33 & 56 & 21 & 14 & 166 & 2.59 & 3 \\
\hline $\begin{array}{l}\text { Fire } \\
\text { wood }\end{array}$ & 11 & 18 & 27 & 40 & 21 & 117 & 3.36 & 4 \\
\hline $\begin{array}{l}\text { Saw dust } \\
\text { stove }\end{array}$ & 4 & 6 & 6 & 22 & 30 & 68 & 4.00 & 6 \\
\hline $\begin{array}{l}\text { Charcoal } \\
\text { stove }\end{array}$ & 2 & 12 & 10 & 26 & 25 & 75 & 3.80 & 5 \\
\hline Dung & 0 & 2 & 2 & 5 & 26 & 35 & 4.57 & 7 \\
\hline
\end{tabular}

1 is the most preferred and 5 is the least preferred.

The preference of the surveyed households for the listed energy types for cooking indicate that cooking with gas is the most preferred. This is followed by the use of electricity, kerosene, wood, charcoal, sawdust and dung respectively (Table 2). The ranking of gas as the most preferred cooking fuel is a pointer to the relatively high level of awareness of the households about the advantages of cooking with gas and this implies that a lot of reduction in GHG emissions through cooking with electricity and biomass (wood, sawdust and dung) can be achieved through some advocacy and support to households by government to acquire gas cylinders and cookers and also some subsidy on the cost of gas. A survey of domestic energy use for cooking in Kaduna metropolis by Manzuma (2016) shows kerosene and wood to be in greater 
use than cooking gas. The responses in Table 2 indicate a high probability by the households to shift towards adoption of the less carbon emitting cooking gas.

Table 3 shows that the level of observance of the listed energy efficiency measures is low with the exception of five measures whose observances are high. The exceptions are closing doors and windows when the $\mathrm{AC}$ is on, use of fans to circulate cooled air, using tight-fitting covers on pots and pans, washing with cold water instead of hot water and unplugging battery chargers when not in use. Most of the identified measures with low levels of observance are related to cooling and ventilation of buildings, provision of lighting and preservation, preparation and cooking of food in the surveyed buildings. These components of domestic energy consumption were reported by Manzuma (2016) to be responsible for about $79 \%$ of total indirect $\mathrm{CO}_{2}$ emissions (i.e. emissions from grid-supplied electricity) from domestic energy consumption in Kaduna metropolis. Manzuma (2016) estimated that about $148.49 \mathrm{tCO}_{2}$ was emitted annually by the surveyed houses as a result of the use of grid electricity for cooking and other activities related to handling of food. Lighting and cooling respectively produced $112.39 \mathrm{tCO}_{2} /$ year and $75.70 \mathrm{tCO}_{2} /$ year.

Table 3: Level of Observance of Energy Efficiency Measures

\begin{tabular}{|c|c|c|c|c|c|c|c|c|}
\hline \multirow[b]{2}{*}{ Energy efficient measures } & \multicolumn{5}{|c|}{ Level of observance } & \multirow[b]{2}{*}{$\sum f$} & \multirow[b]{2}{*}{ Mean } & \multirow[b]{2}{*}{ SD } \\
\hline & 1 & 2 & 3 & 5 & & & & \\
\hline Closing doors and windows when the $\mathrm{AC}$ is on & 98 & 22 & 12 & 16 & 27 & 175 & 2.15 & 1.65 \\
\hline Cleaning AC's air filters at least once a month & 38 & 48 & 37 & 18 & 30 & 171 & 2.73 & 1.44 \\
\hline Using shades to prevent overheating by sun & 52 & 45 & 23 & 23 & 27 & 170 & 2.58 & 1.48 \\
\hline Changing inefficient $\mathrm{AC}$ systems & 40 & 37 & 42 & 23 & 29 & 171 & 2.79 & 1.43 \\
\hline Use of fans to circulate cooled air & 72 & 45 & 29 & 22 & 17 & 185 & 2.28 & 1.59 \\
\hline Using ceiling fans to cool off & 53 & 49 & 37 & 25 & 19 & 183 & 2.50 & 1.50 \\
\hline Replacing incandescent bulbs & 53 & 34 & 50 & 27 & 20 & 184 & 2.60 & 1.47 \\
\hline Using timers to turn lights on and off & 33 & 23 & 51 & 28 & 46 & 181 & 3.17 & 1.42 \\
\hline Use microwaves and toaster ovens & 26 & 36 & 46 & 31 & 35 & 174 & 3.07 & 1.47 \\
\hline Replacing old refrigerators & 27 & 44 & 44 & 32 & 29 & 176 & 2.95 & 1.41 \\
\hline Air drying clothes as against machine drying & 54 & 35 & 26 & 19 & 36 & 170 & 2.69 & 1.45 \\
\hline Keeping the oven door closed while cooking & 57 & 33 & 21 & 33 & 29 & 173 & 2.68 & 1.45 \\
\hline Matching the pot size to the burner on the stove & 53 & 34 & 38 & 29 & 28 & 182 & 2.70 & 1.45 \\
\hline Using tight-fitting covers on pots and pans & 57 & 52 & 35 & 19 & 22 & 185 & 2.44 & 1.52 \\
\hline Washing with cold water instead of hot water & 64 & 38 & 41 & 17 & 21 & 181 & 2.41 & 1.53 \\
\hline Use of solar water heater for energy saving & 27 & 29 & 33 & 32 & 44 & 165 & 2.68 & 1.45 \\
\hline Full loading of washing machine & 29 & 37 & 26 & 34 & 46 & 172 & 3.18 & 1.42 \\
\hline Unplugging battery chargers when not in use & 88 & 33 & 24 & 16 & 27 & 188 & 2.26 & 1.60 \\
\hline
\end{tabular}

1-Very high 2 - High 3 - Low 4- Very low 5 - Does not observe

These practices with low level of observance present yet another set of opportunities for mitigating GHG emissions. Proper enlightenment of households by government agencies and non-governmental organizations (NGOs) concerned with the conservation of environment can contribute to significant reduction of GHGs associated with these inefficient practices. The proportion of emissions attributable to these activities $(79 \%)$ is an indication of the quantum of mitigation that adoption of these measures by the households could achieve in Kaduna metropolis. It is hoped that if inefficient behaviours related to energy consumption at the household level are identified and households are enlightened about and encouraged to embrace the more efficient and sustainable practices regarding these activities, wastage of the scarce energy resources would not only be avoided but the negative impact of such activities on the global climate system will also be reasonably curtailed.

\subsection{BEHAVIOURAL ADAPTATIONS}

Behavioural changes that can bring about significant reduction in energy consumption and consequently GHG emissions by households were identified from existing literature (Levine, Urge-Vorsatz, Blok, Geng, Harvey, Lang,....and Yoshino, 2007; PEW CENTER, 2009; RIBA, 2009; Wilson and Hawkins, 2011; EhrhardtMartinez, 2010). Households were then asked to rank their level of willingness to adopt these energy efficient measures on a scale of $1-5$ where 1 indicate a very high level of willingness by the household and 5 indicates lack of preparedness to adopt such measures. Their responses are as presented in Table 4 . 
It can be observed from Table 4 that majority of the surveyed houses indicated high level of willingness to adopt all but two of the suggested measures that can improve energy use efficiency in buildings and consequently lower emission of GHGs. The measures the households are not too enthusiastic to embrace are improvement of lighting controls by using sensors and solar water heating instead of the use of electricity. The relatively small values of the standard deviations are an indication of the closeness of the willingness of households to adopt the suggested measures to the mean.

Table 4: Willingness of Households to Accept Behavioural Changes

\begin{tabular}{|c|c|c|c|c|c|c|c|c|}
\hline \multirow[b]{2}{*}{ Suggested behavioural changes } & \multicolumn{5}{|c|}{ Willingness to accept } & \multirow[b]{2}{*}{$\sum f$} & \multirow[b]{2}{*}{ Mean } & \multirow[b]{2}{*}{$\mathrm{SD}$} \\
\hline & 1 & 2 & 3 & 4 & 5 & & & \\
\hline Turn off lights and appliances when not in use & 145 & 14 & 11 & 12 & 8 & 190 & 1.56 & 2.01 \\
\hline Task lighting instead of overhead lighting & 73 & 42 & 31 & 24 & 17 & 187 & 2.30 & 1.58 \\
\hline Use daylight for reading, working and living & 100 & 38 & 33 & 11 & 5 & 187 & 1.84 & 1.83 \\
\hline Use of lighter colours on walls and ceiling & 83 & 52 & 23 & 19 & 11 & 188 & 2.06 & 1.64 \\
\hline Replace all incandescent bulbs & 107 & 36 & 23 & 15 & 10 & 191 & 1.87 & 1.81 \\
\hline Keep lights and lighting fixtures clean & 93 & 48 & 27 & 16 & 4 & 188 & 1.88 & 1.80 \\
\hline Reduce heat gain by planting trees & 90 & 47 & 25 & 18 & 11 & 191 & 2.02 & 1.72 \\
\hline Cool food before it goes into the refrigerator & 91 & 47 & 28 & 12 & 9 & 187 & 1.78 & 1.86 \\
\hline Clean the reflectors underneath the burners stovetops & 76 & 50 & 39 & 17 & 8 & 190 & 2.04 & 1.71 \\
\hline Fill the freezer by using water-filled bottles & 69 & 44 & 33 & 23 & 16 & 185 & 2.31 & 1.63 \\
\hline Replacing appliances over ten years old & 61 & 58 & 33 & 22 & 11 & 185 & 2.26 & 1.60 \\
\hline Improve lighting controls by using sensors & 50 & 47 & 38 & 28 & 26 & 189 & 2.65 & 1.46 \\
\hline Clean cooling coils on a regular basis & 59 & 56 & 39 & 18 & 17 & 189 & 2.07 & 1.69 \\
\hline Installation of renewable energy technologies & 72 & 50 & 34 & 18 & 10 & 184 & 2.21 & 1.62 \\
\hline Solar water heating instead of electricity & 59 & 39 & 40 & 19 & 24 & 181 & 2.50 & 1.50 \\
\hline Switching to cool roofs & 82 & 29 & 31 & 26 & 20 & 188 & 2.32 & 1.57 \\
\hline
\end{tabular}

1 - very high willingness, 2 - high willingness, 3 - low willingness, 4 - very low willingness and 5 not willing

\section{CONCLUSION}

The findings reveal a low level of observance of majority of the identified energy efficient measures by the households and also identified that a lot of emission reduction could be achieved from these measures. This is more so as majority of the respondents show a great enthusiasm to adopt a greater number of the suggested measures. This calls for creation of awareness among the residents about energy efficiency and the need to be more energy efficient. This will not only ensure prudent utilization of the insufficient resources but also prevent the adverse effects that careless use would have on the environment in form of emissions, pollution and destruction of ecosystems.

It can also be observed from the findings that the two measures most of the respondents are not so willing to embrace (i.e. improvement of lighting controls by using sensors and solar water heating instead of the use of electricity which is mostly generated from thermal power stations that burn natural gas and coal to produce the steam used in operating the turbines) involve a change of technology and consequently some financial commitment before the issue of behavioural change. So it may be implied that their lack of interest in these measures could be as a result of preconceived notion that it is costly to acquire such equipment. Governments at all levels can play a role here by assisting in ensuring availability of these technologies at affordable costs to the households. This can be through encouragement of local production through incentives to the manufacturers and distributors.

\section{REFERENCES}

Awosope, C. A. (2014). Nigeria Electricity Industry: Issues, Challenges and Solutions. Retrieved from covenantuniversity.edu.ng/content/downl oad/35621/.../1/.../38th +Public +Lecture. $p d f$

BPE (2011). Electric Power Investors' Forum. Power Generation (status and outlook). Retrieved from www.nigeriaelectricityprivatisation.com/ wp-content/plugins/download.phd?id=27

Department of Energy and Climate Change (2015). Valuation of energy use and greenhouse gas (GHG) emissions. Retrieved from https://www.gov.uk/

Ehrhardt-Martinez, K. (2010). Changing Habits, Lifestyles and Choices: The Behaviours that Drive Feedback-Induced Energy Savings. Retrieved from web.stanford.edu/.../behavior/.../Ehrhardt Martinez\%20ECEEE\%20Feedback\%20 Beh.. 
Erickson, P., Heaps, C. and Lazarus, M. (2009). Greenhouse Gas Mitigation in Developing Countries Promising Options in China, Mexico, India, Brazil, South Africa, and South Korea. Retrieved from https://www.energycommunity.org/docu ments/WorkingPaperUS09-03.pdf

Global Commission on the Economy and Climate (2015). New Climate Economy Technical Note: Abatement Reduction Potential. Retrieved from http://newclimateeconomy.report/workin gpapers/wp-

content/uploads/sites/5/2016/04/NCEtechnical-note-emission-reductionpotential_final.pdf

Gupta, R. and Garrigan, C. (2013). Developing and Testing a Global Common Carbon Metric Approach for Measuring Energy use and Greenhouse Gas Emissions from Building Operations. In Soetanto, R., Tsang, N. and Ahmed, A. (Eds) Integrated Approaches to Sustainable Building: Developing Theory and Practice through International Collaboration and Learning. Proceedings of sustainable Building and Construction Conference, 3-5 July 2013, Coventry University, UK

Ibrahim, F. (2015). Power failure: Nigerians burn N17.5tn fuel on generators in five years. Retrieved from http://punchng.com/power-failurenigerians-burn-n17-5tn-fuel-ongenerators-in-five-years/

International Energy Agency (2013). $\mathrm{CO}_{2}$ Emissions from Fuel Combustion. Retrieved from http://www.iea.org/termsandconditionsus ecopyright/

Israel, G. D. (2013). Determining Sample Size. Retrieved from http://edis.ifas.ufl.edu/pdffiles/PD/PD00 600.pdf

Kaduna State (2010). Kaduna State Vision 2020

Kaduna state ministry of land, survey and country planning (2015). Kaduna Master Plan final report. MLC Press, University of Westminster, London.

Levine, M., Ürge-Vorsatz, D., Blok, K., Geng, L., Harvey, D., Lang, S., Levermore, G., Mongameli Mehlwana, A., Mirasgedis, S., Novikova, A., Rilling, J. and Yoshino, H. (2007). Residential and Commercial Buildings. In Climate Change 2007: Mitigation. Contribution of Working Group III to the Fourth Assessment Report of the Intergovernmental Panel on Climate Change [B. Metz, O.R.
Davidson, P.R. Bosch, R. Dave, L.A. Meyer (eds)], Cambridge University Press, Cambridge, United Kingdom and New York, NY, USA. Retrieved from http://www.ipcc.ch/pdf/assessmentreport/ar4/wg3/ar4-wg3-chapter6.pdf

Lin T, Yu Y, Bai X, Feng L, Wang J (2013) Greenhouse Gas Emissions Accounting of Urban Residential Consumption: A Household Survey Based Approach. PLoS ONE 8(2): e55642. doi:10.1371/journal.pone.0055642

Manzuma, B. M. (2016). Framework for Residential Greenhouse Gas Mitigation in Kaduna Metropolis, Nigeria. An unpublished Ph.D. Progress Seminar presented at the Faculty of Environmental Design, Ahmadu Bello University, Zaria, Nigeria

Mbamali, I., Stanley, A. M. and Zubairu, I. K. (2012). Evironmental, Health and Social Hazards of Fossil Fuel Electricity Generators: A Users' Assessment in Kaduna, Nigeria. Retrieved from http://www.aijcrnet.com/journals/Vol_2_ No_9_September_2012/28.pdf

Mills, E. (2011). Building commissioning: a golden opportunity for reducing energy costs and greenhouse gas emissions in the United States. Retrieved from https://link.springer.com/content/pdf/10. 1007\%2Fs12053-011-9116-8.pdf

Mohammed, O. (2015). Nigeria's electricity crisis is so bad that people are spending three times more running back-up generators. Retrieved from http://qz.com/474526/nigeriaselectricity-crisis-is-so-bad-people-spendthree-times-more-running-back-upgenerators/

Ndabula, C., Jidauna, G. G., Averik, P. D., Oyatayo, T. K., Abaje, I. B. and Ali, A. Y. (2014). Characterization of sprawling in Kaduna metropolitan area. Retrieved from http://article.sciencepublishinggroup.com /pdf/10.11648.j.ajep.20140303.14.pdf

NPC (2009a). 2006 Population and Housing Census Priority Tables. National and State Population and Housing Tables. Priority Tables Volume I Retrieved from http://www.population.gov.ng/images/Pri ority\%20Tables\%20Volume\%20Iupdate.pdf

NPC (2009b). 2006 Population and Housing Census of the Federal Republic of Nigeria. Housing Characteristics and Amenities Tables. Priority Tables Volume II. Retrieved from 
http://www.population.gov.ng/images/Pri ority $\% 20$ Tables $\% 20$ Volume $\% 20$ IIupdate.pdf

Olaleye, S. O. and Akinbode, S. O. (2011). Analysis of Households' Demand for Alternative Power Supply in Lagos State, Nigeria. Retrieved from http://maxwellsci.com/print/crjss/v4-121127.pdf

PEW CENTER (2009). Buildings Overview. Retrieved from http://www.c2es.org/technology/overvie w/buildings

RIBA (2009). Principles of Low Carbon Design and Refurbishment. Retrieved from http:www.architecture.com/files/ribahold ings/policyandinternationalrelations/poli cy/environment/

Stanley, A. M. and Mbamali, I. and Dania, A. A. (2012). Effect of fossil-fuel electricity generators on indoor air quality in Kaduna Nigeria. Retrieved from http://www.abu.edu.ng/publications/2012 -03-30-061936_3144.pdf

Sun, M., Yuan, Y., Zhang, J., Wang, R. and Wang, Y (2014). Greenhouse gas emissions estimation and ways to mitigate emissions in the Yellow River Highefficient Eco-economic Zone, China. Elsevier Journal of Cleaner Production, $81 \quad$ (2014) 89-102. http://dx.doi.org/10.1016/j.jclepro.2014.0 6.032

Swinand, G. P. and O'Mahoney, A. (2014). Estimating the impact of household energy savings measures for Ireland using the BER database. Retrieved from www.ssisi.ie/SSISI_BER_Paper_GSwin and_AOMahoney_200415_final.pdf

Takaoka, M. V. (2011). SBCI Common Carbon Metric. Retrieved from http://www.urbangateway.org/sites/defau 1t/ugfiles/8701_36688_Marcelo_takaoka. pdf

The Ministry of Environment of the Federal Republic of Nigeria (2003). Nigeria's
First National Communication Under The United Nations Framework Convention On Climate Change. Retrieved from http://unfccc.int/resource/docs/natc/nignc 1.pdf

UNEP (2007). Buildings and Climate Change: Status, Challenges and Opportunities. Retrieved from www.unep.org/sbci/pdfs/SBCIBCCSummary.pdf

UNEP (2009). Buildings and Climate Change: Summary for Decision-Makers. Retrieved from

http://www.unep.org/sbci/pdfs/SBCIBCCSummary.pdf

UNEP (2012). Global Initiative for Resource Efficient Cities. Retrieved from www.unep.org/pdf/GI-REC_4pager.pdf

UNEP (2015). District Energy in Cities. Retrieved from http://www.districtenergyinitiative.org/

UNEP (n.d). Cities and Buildings. Retrieved from www.unep.org/.../Cities_and_BuildingsUNEP_DTIE_Initiatives_and_projects_h d.pd...

UNEP SBCI (2009). Common Carbon Metric for Measuring Energy Use \& Reporting Greenhouse Gas Emissions from Building Operations. Retrieved from http://www.unep.org/sbci/pdfs/uNEPSBc icarbonmetric.pdf

Wang, X.; Huang, C and Zou, Z. (2016). The analysis of energy consumption and greenhouse gas emissions of a large-scale commercial building in Shanghai, China. Retrieved from http://journals.sagepub.com/doi/pdf/10.1 $177 / 1687814016628395$

Wilson, T. and Hawkins, L. (2011). Changing Household Energy Behaviours: Key Findings from a Review of Applied Research. Retrieved from www.gov.scot/Resource/Doc/175 